\title{
EXPERIMENTAL STUDIES OF THE EFFECT OF ELECTROSURGICAL AND STANDARD TECHNIQUES ON PANCREATIC RESTORATION
}

DOI: 10.36740/WLek202005113

\author{
Kateryna G. Valikhnovska', Iryna M. Savytska², Prysyazhna R. Nataliya², Yaroslav Y. Voitiv ${ }^{2}$ \\ 'SHUPYK NATIONAL ACADEMY OF POSTGRADUATE EDUCATION, KYIV, UKRAINE \\ 2STATE INSTITUTE «NATIONAL SHALIMOV INSTITUTE OF SURGERY AND TRANSPLANTATION», NATIONAL ACADEMY OF MEDICAL SCIENCES OF UKRAINIAN, \\ KYIV, UKRAINE
}

\begin{abstract}
The aim: There have been investigated the specific features of pancreatic resection with the use of electrosurgical methods on experimental models of clinical operations. Pancreatic tissue regeneration at the surgical site have been studied when employing monopolar, bipolar, electric welding methods as compared with standard surgical technique. Materials and methods: The study was performed on 40 white laboratory rats. Pancreatic resection was conducted by standard surgical technique or by welding with electrocoagulation device "Patonmed EWD-300", high-energy electrosurgical device in bipolar mode and in monopolar mode. The pancreatic tissue was examined immediately after the surgery and at 3,7 and 21 days postoperatively.

Results: In early terms following standard surgery there was seen more severe inflammation and the volume of newly formed connective tissue got increased faster than after the electrosurgical technique. Pancreatic ducts developed in newly formed tissue after the use of each type of electroresection, whereas that event was not observed following standard surgery. When using electrosurgery in monopolar mode, the area of coagulative necrosis was found to be less dense than after resection performed in bipolar mode. Conclusions: Based on the findings, we can conclude that each of the above types of electroresection reduces surgery time, lowers bleeding risks, contributes to formation of the more adequate sealing on the resection surface with no complications of the recovery process.
\end{abstract}

KEY WORDS: regeneration, pancreas; electric welding of tissues; electrosurgery; monopolar welding; bipolar welding

\section{INTRODUCTION}

Surgical interventions on the pancreas have always been a challenge due to the features of the anatomical structure. Despite the latest developments in modern surgery, some issues still need addressing. High-frequency electrosurgical instruments are widely used in various branches of medicine. They are employed in gynecology and abdominal surgery, in proctology and thoracic surgery, in ophthalmology and urology $[1,2,3,4]$.

High frequency electric welding technology reduces the time of surgical intervention, does not require suture materials, not only minimizes the duration of bleeding, but also disinfects the wound surface $[5,6]$. The use of electrosurgical instruments significantly reduces the time of surgical intervention and wound pain in the postoperative period [7]. However, there is limited data on changes that occur in the pancreatic tissue resulting from the use of electrosurgical instruments during resection interventions.

\section{THE AIM}

The aim was to investigate the features of changes in the tissues of the pancreas after resections performed with the use of standard surgical techniques and electrosurgical methods: electric welding, bipolar welding and monop- olar welding, to analyze the possibilities and feasibility of their use.

\section{MATERIALS AND METHODS}

The study was performed on 40 six-month old rats of the genus Rattus, (family Muridae), weighing 240-280 g. Before the research, a veterinary examination was conducted, and the animals had a group health passport with the necessary preventive measures. The animals were treated and anesthetized as required by the Law of Ukraine "On Protection of Animals from Cruel Handling" No. 1759-IV dated December 15, 2009, the Ordinance of the Cabinet of Ministers of Ukraine dated July 28, 2010 No. 1585 "On Approval of the List of Regulatory and Legal Acts Protecting Animals from Ill-treatment", and Scientific and Practical Guidance for Housing and Care. of Laboratory Animals and Their Use issued by the National Pharmacological Centre, Ministry of Health of Ukraine (Protocol No. 8 dated June 22, 2012). According to the Ethics Committee of Shupyk National Academy of Postgraduate Education during the bioethical examination of the experimental study on compliance with the principles and norms of bioethics established its full compliance with the current norms and standards (23.10.2017, Protocol No. 8). 
According to the assigned objectives, the animals were divided into four groups.

Animals of group I $(\mathrm{n}=10)$ underwent the resection of part of the pancreas with the use of conventional surgical technique. These animals composed the comparison group.

In animals of the group II $(n=10)$, the resection of part of the pancreas was performed using the electrosurgical tool in a monopolar mode (high-energy electrosurgical device functioning at 80 watts).

Animals of group III $(n=10)$ had a part of the pancreas resected employing Patonmed EKVZ-300 D device in a manual welding mode (mode DA2).

Group IV $(n=10)$ included animals that had part of the pancreas removed using bipolar electrosurgery (high-energy electrosurgical device functioning at 30 watts).

Operative interventions were performed under general intraperitoneal anesthesia $(0.2 \mathrm{ml}$ of $5 \%$ sodium thiopental and $0.4 \mathrm{ml}$ of $1 \%$ propofol) under aseptic and antiseptic conditions. To prevent postoperative complications, a single injection of bicillin-5 at a dose of 1 million units per $\mathrm{kg}$ of body weight was administered.

To provide the analgesic effect within the first three postoperative days, dexketoprofen was injected subcutaneously (3-5 $\mathrm{mg} / \mathrm{kg}$ of the body weight).

At three, seven and twenty-one days following the end of the experiment the animals were euthanized with an intra-abdominal overdose of $10 \%$ sodium thiopental. The pancreatic tissue in the resection site was investigated immediately after surgery and after 3, 7, 21 days.

To prepare samples for histological studies, the part of the pancreas was excised with the resection area, the sample was fixed for 24 hours in 10\% neutral-buffered formalin, and then it was embedded in paraffin according to a routine protocol. Five- $\mu \mathrm{m}$-thick tissue sections were stained with hematoxylin and eosin, azure-II-eosin, Van Gieson's picrofuchsin; the PAS-reaction and PAS-reaction with amylase control were conducted. The histological samples were studied using the Leica DM500 light optical microscope, the images were captured by the Leica ICC 50 HD camera.

Statistical analysis and processing of the results were carried out using the IBM SPSS Statistics 20 Integrated Software Package. The non-parametric Kruskal-Wallis $\mathrm{H}$ test and the Mann-Whitney $\mathrm{U}$ test were employed as criteria for the reliability of the difference.

\section{RESULTS}

Immediately after resection using a conventional technique, the blood vessels were dilated, the arteries were atonic. On resected surface the blood clot with cell body fragments was loose; there were seen hemorrhages in the stroma. In some areas under the resection area, multiple hemorrhages were merging into large fields, affecting the trophic support of the parenchyma, which had undergone dystrophic changes.

After three days, a necrotic focus arose in the resection site; granulation tissue began to form around it. Alongside with impaired vascular penetrability there was seen plas- morrhagia, diapedetic hemorrhages, and stromal edema even in the remote areas. Inflammation with abundant neutrophilic and lymphocytic infiltration of the stroma covered a significant part of the pancreas.

After seven days, a thick layer of granulation tissue with necrotic foci was formed in the resection site, the stroma was infiltrated mainly with neutrophils and lymphocytes, and under the resection area, edema was more pronounced. Dystrophic changes in pancreatocytes were particularly prominent in the resection site, and somewhat decreased in the remote areas.

After 21 days, the formation of adhesions with loops of the small intestine was mainly seen. Inflammatory manifestations were still observed in the tissues adjacent to the resection site. The areas of necrotic parenchyma were surrounded by a thick connective tissue capsule, the wall of which was mainly infiltered by neutrophils (Fig. 1). In remote areas, the functional state of parenchymal cells somewhat recovered. Manifestations of the vascular response were less pronounced than in the prior time points.

Immediately after monopolar welding, a layer of coagulation-altered tissue was formed on the resection surface. The underlying pancreatic tissue became compact due to the dehydration and compression; under this area, there was seen a loss of cellular communication in the parenchy$\mathrm{ma}$, in this area, there were isolated hemorrhages, blood vessels were thrombosed (Fig. 2). The underlying vessels were dilated and plethoric.

After three days, around the thermal injuries in the parenchyma, there was formed a thin layer of fibroblasts and collagen fibers, which began to separate the damaged areas from the intact parenchymal areas. Pancreatocytes did not preserve the zonation around the damage area; they were undergoing dystrophic changes. Blood vessels under the resection area were dilated, the pancreatic stroma became swollen even in the remote areas.

After seven days, the necrotic pancreatic parenchyma was surrounded by a connective tissue capsule, the coagulation scab was divided into separate fragments due to the effect of tissue enzymes and macrophage activity. The separation of the pancreatic cytoplasm into homogeneous and zymogenic areas partially recovered in the areas remote from the affected site. Edema and a vascular response persisted.

After 21 days, there was seen a significant decrease in the severity of inflammatory response, in the areas remote from the resection site, pancreatocytes were recovering the functional activity as evidenced by the restoration of the cytoplasmic zonation. The manifestations of edema significantly decreased, vessels of the microcirculatory bloodstream were restoring. The cicatrix on the resected surface was formed by mature loose connective tissue, where there were noted clusters of tissue basophils with no signs of degranulation (Fig. 3).

After electric welding, on the resection surface, the coagulation scab was formed predominantly by coagulated plasma and fragments of cell bodies, it had clefts (Fig. 4). Under the scab, the pancreatic parenchyma became densified due to a reduced volume of cell bodies, liquid loss, 


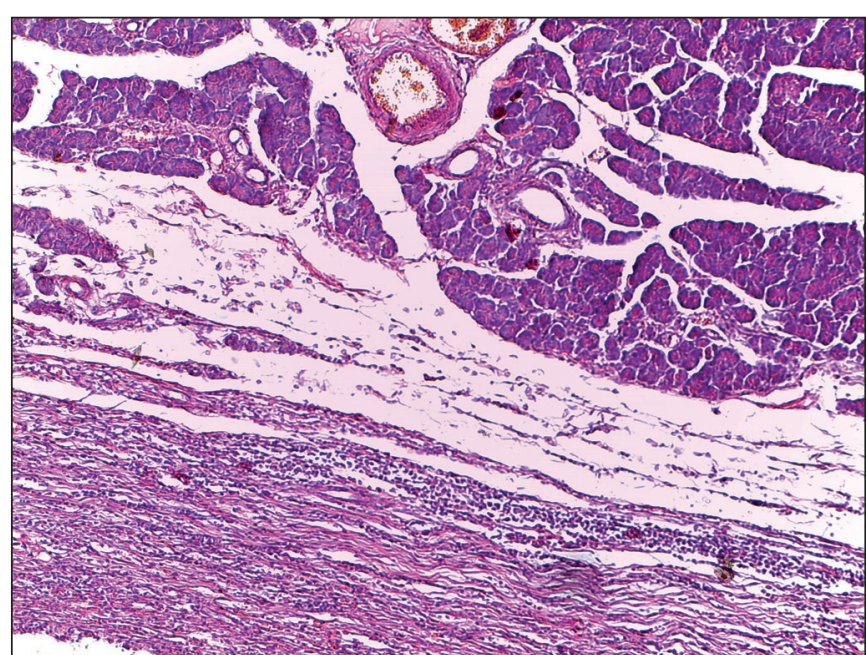

Fig.1. The pancreas of the white rat 21 days after the conventional surgery. Azure-II-eosin staining. Magnification x100.

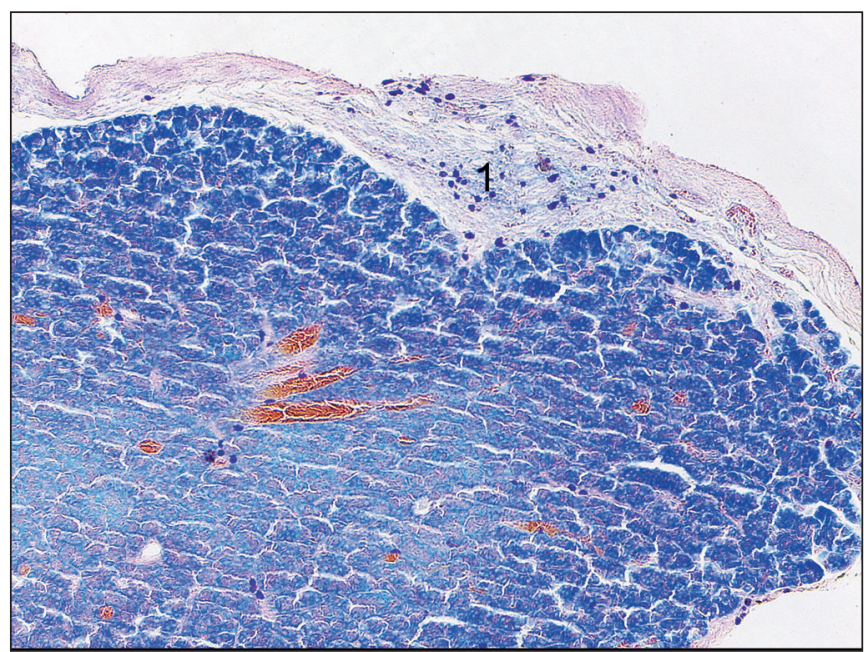

Fig. 3. White rat pancreas in the resection site 21 days after monopole welding. 1 - a cluster of tissue basophils. Hematoxylin and eosin staining. Magnification x100.

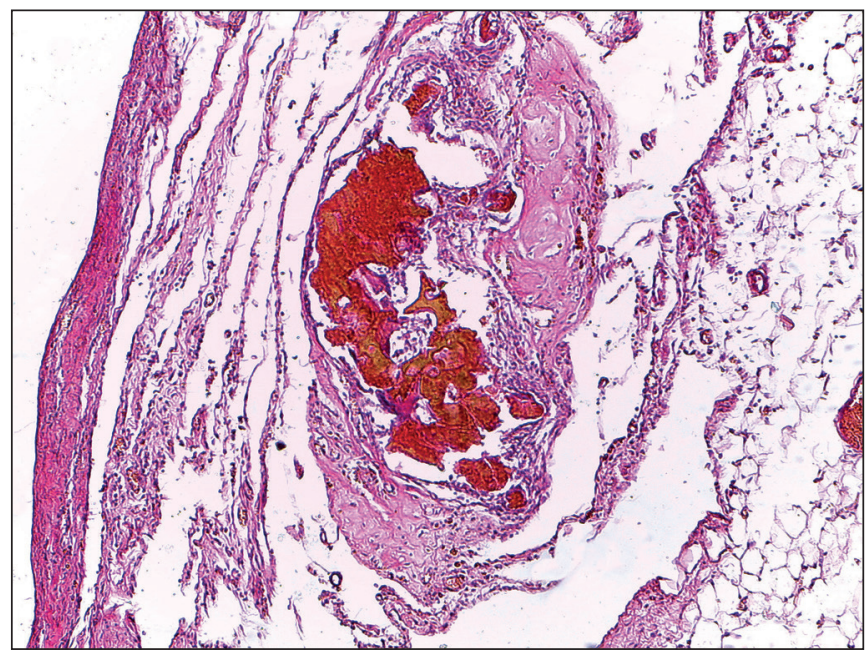

Fig. 5. The remains of coagulation scab 21 days after electric welding. Hematoxylin and eosin staining. Magnification x100.

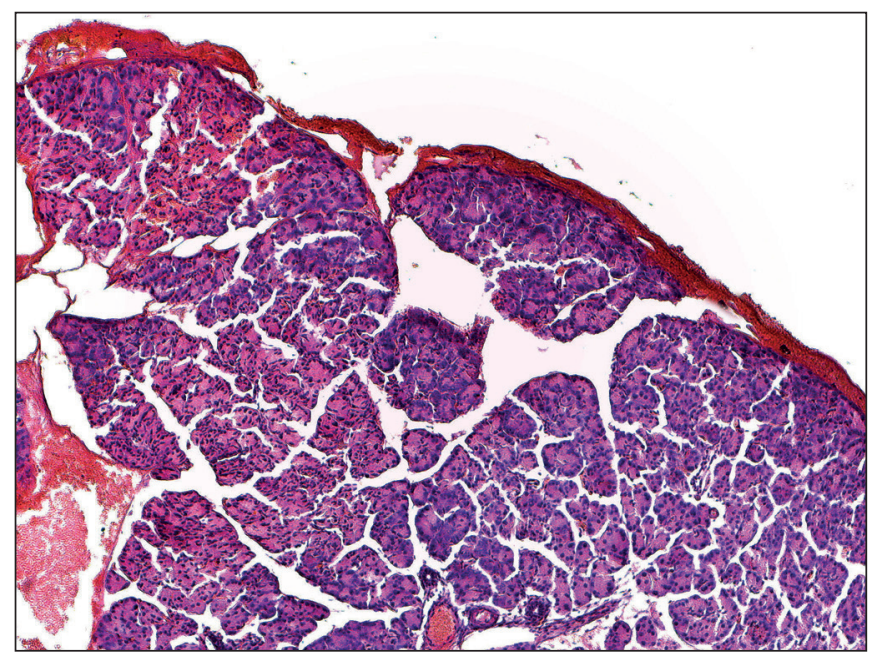

Fig. 2. White rat pancreas in the resection site after monopole welding. Hematoxylin and eosin staining. Magnification x100.

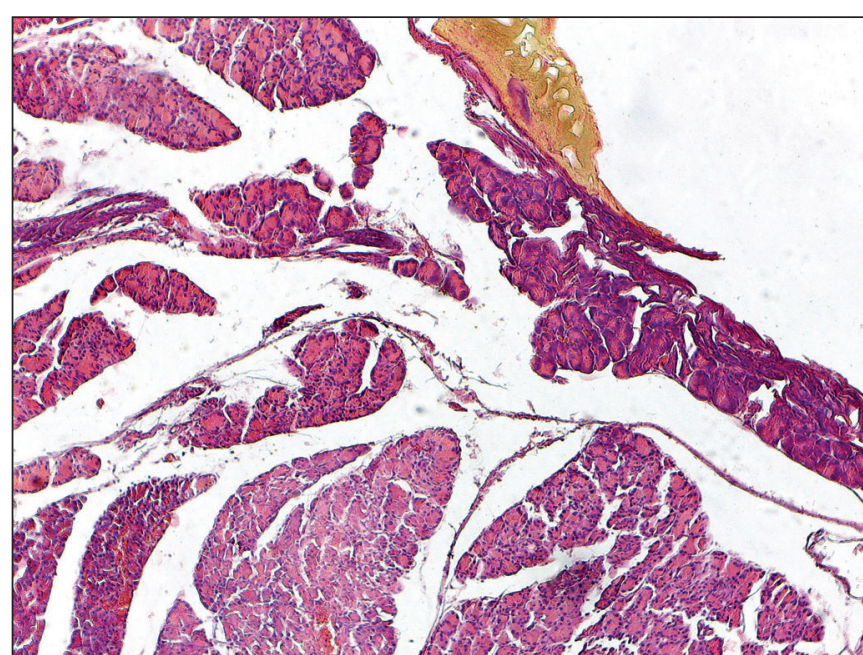

Fig. 4. Pancreas of the white rat in the resection site after electric welding. Hematoxylin and eosin staining. Magnification x100.

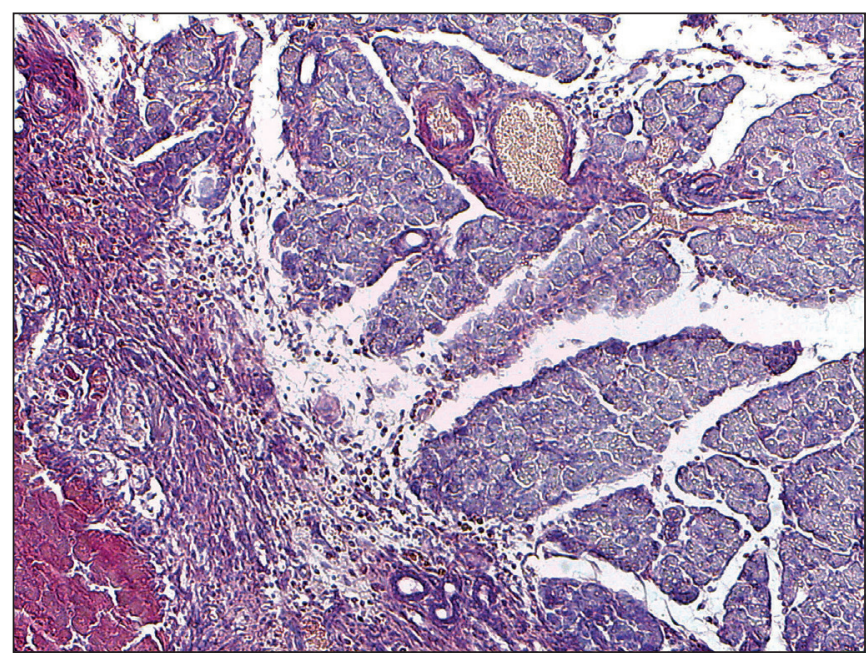

Fig. 6. White rat pancreas in the area of bipolar welding after 7 days. The coagulation necrosis zone is separated by a connective tissue capsule. Hematoxylin and eosin staining. Magnification x100. 
Table I. Thickness of the thermal injuries after the pancreatic resection $(\mu \mathrm{m})$

\begin{tabular}{cccc}
\hline Values & $\begin{array}{c}\text { Group II } \\
\text { Monopolar } \\
\text { welding }\end{array}$ & $\begin{array}{c}\text { Group III } \\
\text { Electric } \\
\text { welding }\end{array}$ & $\begin{array}{c}\text { Group IV } \\
\text { Bipolar } \\
\text { welding }\end{array}$ \\
\hline Width of coagulation scab & 88,76 & $66,39^{*}$ & $96,15^{*}$ \\
\hline Width of the densified area & 328,26 & $236,11^{*}$ & $403,17^{*}$ \\
\hline Width of the area with lost cellular communication & 785,35 & $553,41^{* *}$ & $816,64^{* *}$ \\
\hline
\end{tabular}

Note: * - the reliability of the difference between the groups according to the Kruskal-Wallis $\mathrm{H}$ test $(\mathrm{p}=0.001)$;

** - the reliability of the difference between the groups according to the Mann-Whitney $U$ test.

intracellular coagulation and compression caused by the jaws of the electric instrument. Blood vessels were closed, compressed. There were small isolated hemorrhagic foci; there was a mosaic distribution of densified tissue areas among the areas of parenchyma with lost cellular communication.

After three days, in the resection site, the coagulation scab was partially fragmented and, along with the necrotic pancreatic parenchyma it was surrounded by a thin layer of fibroblasts. Under the resection site, in all sections of the microcirculatory bloodstream, there were changes, including stasis, detachment of the endothelial cells into the lumen of the vessels, hemorrhagic infiltration of the vascular walls and paravasal connective tissue.

After seven days, fragments of the coagulation layer and the necrotic pancreatic tissue were surrounded by a connective tissue capsule, where new ducts and blood vessels were formed. The functional status of pancreatic cells under the resection area partially recovered, but the blood vessels remained dilated.

After 21 days, on the surface of the resection site, there was formed mature and loose connective tissue containing new ducts and blood vessels. In this tissue, there were also seen fragments of coagulation scab. The remains of the coagulation scab were often rejected from the surface of the pancreas and seen in the abdominal cavity adherent to omentum (Fig. 5). The signs of inflammation almost faded in the newly formed tissue and in the surrounding parenchyma.

After resection with bipolar welding, a coagulative scab was seen on the resected surface. It was formed by a sharply compacted and dehydrated pancreatic tissue and clotted blood. Under the scab, the tissue was also compacted, the cells became spindle-shaped, the volume of the cytoplasm decreased significantly, the nuclei were pictonized, hyperchromic. In the parenchyma under this layer, there were gaps that resulted from the evaporation of the liquid. There were seen minor hemorrhages in the stroma. In the remote areas, mainly capillaries and veins were plethoric. In pancreatocytes, the intensity of differentiation into homogeneous and zymogenic zones decreased. Three days after bipolar welding, under the resection zone, the damaged parenchyma was separated from the preserved parenchyma by a thin layer of connective tissue. The stromal edema was pronounced below the resection zone; at the distance, it somewhat faded away. The blood vessels dilated, especially under the resection area. At 7 days, in the lesion area, the coagulated gland tissue was completely covered by a vascularized connective tissue capsule. In the capsule closer to the preserved parenchyma, ducts and blood vessels formed (Fig. 6). Fragments of a coagulation scab were seen under the capsule in the newly formed granulation tissue. They were lysed, surrounded by macrophages. Signs of stromal edema were observed at a distance. Cytoplasm of exocrine pancreatocytes was poorly basophilic; insulocytes had more pronounced signs of dystrophy. Stroma infiltration was virtually absent.

Twenty-one days after bipolar welding, in the resection zone, a scar formed by a moderately dense connective tissue, where single fragments of coagulated pancreatic tissue were noted. Under the resected area, pancreatocytes showed signs of moderate dystrophic changes. At a distance, the manifestations of dystrophy faded away, the zoning of the cytoplasm of exocrine pancreatocytes was restored.

\section{DISCUSSION}

When using electrosurgical methods, a hermetic layer formed on the resection surface, which ensured reliable hemostasis, contributing to a greatly reduced risk of bleeding and promoting the recovery processes in the postoperative period. The area of the thermally damaged tissue was less with the use of electric welding as compared with monopolar welding and bipolar welding.

The site of the pronounced thermal damage was of heterogeneous structure and various volume, depending on the electrosurgical method. Visually, it was possible to distinguish three areas of changes: 1) a dense coagulation scab formed on the surface; 2 ) the parenchyma was densified, it was difficult to visualize the cellular boundaries, the nuclei diminished in volume and became hyperchromic; 3) pancreatic cells lost contact with each other.

The comparative analysis of independent data (groups II, III and IV), using the non-parametric Kruskal-Wallis $\mathrm{H}$ test, revealed statistically significant differences in such values as the width of the coagulation scab, the width of the densified area and the area with lost cellular communication between the two groups $(\mathrm{p}=0.0001)$ (Table. I). For the densified area width there was employed the non-parametric Mann-Whitney U test involving the analysis of two independent samples. 
More pronounced damage to the pancreatic parenchyma during surgery with the use of monopolar welding and bipolar welding slowed down the recovery processes as evidenced by the investigations at 3 and 7 days postoperatively, however, at 21 days, the difference between the injuries caused by three electrosurgical methods were somewhat smoothed out.

In the early stages after the use of the conventional surgical technique, there was seen a more pronounced inflammation, there occurred bleeding on the resection surface and hemorrhage in the stroma, the volume of newly formed connective tissue increased significantly. Further, it could lead to postoperative bleeding, increase the duration of reparative processes, and cause the formation of a significant amount of cicatricial tissue.

\section{CONCLUSIONS}

When using monopolar, bipolar and electric welding, reliable hemostasis was observed due to the formation of coagulation scab on the resected surface and blood coagulation in the vessels under the resection area. The underlying vessels were markedly dilated, preserving patency. With the use of conventional technique there occurred bleeding on the resection surface and hemorrhage in the stroma.

Electric welding caused more considerable tissue compaction and liquid evaporation in the resection area than monopolar and bipolar welding. However, the volume of the thermally damaged tissue was less, which significantly reduced the area of necrotic parenchyma.

In the early stages after the use of conventional surgical technique, there was a more pronounced inflammation with the dominance of neutrophil infiltration than after electrosurgical methods.

With the use of conventional surgical technique the volume of newly formed connective tissue increased faster than after electric welding, which further could lead to the formation of a considerable amount of cicatricial tissue.

The cicatrices formed in the resection site at 21 days both after electric, monopolar and bipolar welding were moderately thin and did not cause the deformation of the pancreas.

The use of electrosurgical methods allowed reducing the time of surgery, lessened the risk of bleeding, promoted more compact connection on the resection surface, and did not affect recovery processes in the investigated periods.

\section{REFERENCES}

1. Meeuwsen F.C., Guédon A.C., Arkenbout E.A., et al. The art of electrosurgery: trainees and experts. Surg Innov. 2017; 24(4):373-378. doi: 10.1177/1553350617705207.

2. Hainer B.L. Fundamentals of electrosurgery. J Am Board Fam Pract. 1991; 4(6):419-26.

3. Taheri A., Mansoori P., Sandoval L.F., et al. Electrosurgery: part II. Technology, applications, and safety of electrosurgical devices. J Am Acad Dermatol. 2014; 70(4):607.e1-607.e12. doi: 10.1016/j. jaad.2013.09.055.

4. Advincula A.P., Wang K. (2008). The evolutionary state of electrosurgery: where are we now? Curr Opin Obstet Gynecol. 20(4):353-8. doi: 10.1097/ GC0.0b013e3283073ab7.
5. Morris M.L., Tucker R.D., Baron T.H., Song L.M. Electrosurgery in gastrointestinal endoscopy: principles to practice. Am J Gastroenterol. 2009; 104(6):1563-74. doi: 10.1038/ajg.2009.105.

6. Sukhin I.A., Khudetskyi I.Yu., Kachan S.H., Bilylovets O.M. Investigation of influence on parenchymatous organs of high-temperature methods of tissue dissection and coagulation in the experiment. Clin. surgery. 2013; 1:76-8.

7. Linchevskyy 0., Makarov A., Getman V. Lung sealing using the tissuewelding technology in spontaneous pneumothorax. Eur J Cardiothorac Surg. 2010; 37(5):1126-8. doi: 10.1016/j.ejcts.2009.11.017.

8. Shapovalova Y.A. Kryteriyi efektyvnosti elektrychnoho zvaryuvannya m'yakykh tkanyn dlya zabezpechennya hemostazu pry laparoskopichnykh operatsiyakh [Criterions of efficacy of the soft tissues electric welding for the hemostasis guaranteeing in laparoscopic operations]. Klin Khir. 2015; 8:17-20. (UA)

9. Alkatout I., Schollmeyer T., Hawaldar N.A., et al. Principles and safety measures of electrosurgery in laparoscopy. JSLS. 2012;16(1):130-9. doi: 10.4293/108680812X13291597716348.

10. Huschak G., Steen M., Kaisers U.X. Principles and risks of electrosurgery. Anasthesiol Intensivmed Notfallmed Schmerzther. 2009; 44(1):10-3. doi: $10.1055 / \mathrm{s}-0028-1128179$.

11. Aird L.N., Brown C.J. Systematic review and meta-analysis of electrocautery versus scalpel for surgical skin incisions. Am J Surg. 2012; 204(2):216-21. doi: 10.1016/j.amjsurg.2011.09.032.

The research highlighted in the article became a fragment of the research work of the Department of Surgery and Transplantology of the Shupyk National Medical Academy of Postgraduate Education on the topic: «Development of modes of high-energy methods of coagulation in resection of parenchymal organs and evaluation of their effectiveness (experimental study)» State Registration Number 0117U000907, deadline 2017-2020.

\section{ORCID and contributionship:}

Kateryna G. Valikhnovska - 0000-0001-8287-0736

Iryna M. Savytska - 0000-00020-2749-7825 ${ }^{A, F}$

Prysyazhna R. Nataliya - 0000-0002-6463-2715 ${ }^{\mathrm{C}}$

Yaroslav Voitiv - 0000-0003-2638-9352 ${ }^{E}$

\section{Conflict of interest:}

The Authors declare no conflict of interest

\section{CORRESPONDING AUTHOR Kateryna G. Valikhnovska}

Shupyk National Academy Of Postgraduate Education,

Kyiv, Ukraine

tel: +380502358587

e-mail: Kgv.112@gmail.com

Received: 22.01 .2020

Accepted: 03.04 .2020
A - Work concept and design, B - Data collection and analysis, C - Responsibility for statistical analysis, D-Writing the article, $\mathbf{E}$-Critical review, $\mathbf{F}$ - Final approval of the article 